\title{
Свобода слова в Україні
}

\section{Т. О. Приступенко}

Інститут журналістики КНУ імені Тараса Швченка, Київ, Україна

Paper received 16.03.18; Accepted for publication 25.03.18.

\section{https://doi.org/10.31174/SEND-HS2018-169VI28-09}

Анотація. Обгрунтовано важливість дотримання свободи слова для сучасного українського суспільства. Досліджено зміни стану свободи слова в Україні за оцінками міжнародних рейтингів та українського Інституту масової інформації. Розглянуто зміну форм проявів порушень свободи слова у 2013-2017 рр.. Доведено доцільність реалізації заходів інформаційної безпеки з обмеження діяльності російських ЗМІ та їх відповідність міжнародному і національному законодавству щодо свободи слова.

Ключові слова: свобода слова, засоби масової інформації, медіа, журналістська діяльність, порушення свободи слова.

Вступ. Обраний Україною шлях євроінтеграції та розвитку демократії передбачає забезпечення надійних гарантій та фактичну реалізацію прав і свобод громадян в політичній, економічній, громадській, соціальній, культурній сферах. Ознакою демократичних країн є додержання прав людини та забезпечення їх пріоритету над правами держави, а одним 3 невід'ємних елементів демократичного суспільства $є$ право на свободу слова, що гарантується ст. 10 Конвенції про захист прав людини і основних свобод (далі - Конвенція) [8], ст. 34 Конституції України [9] та низкою інших міжнародних та національних нормативноправових актів. Питання реального дотримання свободи слова є вкрай актуальними, особливо в існуючих умовах трансформації українського суспільства на шляху до формування справедливої та цивілізованої європейської держави.

Короткий огляд публікацій. Проблема забезпечення свободи слова є комплексною та багатоаспектною, вивчається значною кількістю науковців з урахуванням правового, політичного, філологічного, історичного, філософського контекстів. Так, вивченню особливостей правового регулювання свободи слова та дотримання міжнародного законодавства у відносинах влади та засобів масової інформації присвячені роботи В. І. Павликівського [10], проблематика свободи слова та роботи медіа є сферою наукових інтересів Т.В. Романенко [15], вплив політичних процесів на свободу слова розглядається О.О. Заславською [6] Ю.В. Бондарем [4] та ін. Дослідження порушень свободи слова регулярно проводяться міжнародними та національними громадськими організаціями (ОБСЄ [14], Freedom House [17], «Репортери без кордонів», Українська Гельсінська спілка 3 прав людини УГСПЛ $[11,16]$, Інститут масової інформації $[1,2,3]$ тощо).

Метою даного дослідження виступає аналіз сучасного стану свободи слова та забезпечення права на свободу слова у діяльності українських засобів масової інформації.

Матеріали та методи. Матеріалами вивчення проблематики свободи слова в Україні виступають аналітичні огляди та звіти міжнародних і українських неурядових правозахисних організацій, монографії, навчальні посібники, статті у періодичній літературі та пресі. Дослідження було проведене із застосуванням загальнологічних методів і прийомів пізнання (аналі- зу, синтезу, узагальнення, індукції, дедукції, системного підходу).

Результати та їх обговорення. Свобода слова виступає основним принципом діяльності засобів масової інформації (ЗМІ) та є компонентом в системі забезпечення громадського контролю над діяльністю владних органів. Відповідно, однією з ключових гарантій свободи слова $\epsilon$ свобода преси, яка із розвитком нових засобів комунікації трансформувалася у свободу масової інформації [12]. Оскільки переважна більшість українських медіа $є$ власністю певних промислово-фінансових або політичних груп, постійно існує загроза втрати притаманних 3МІ функцій посередника між владою і суспільством, перетворення їх на знаряддя політичного впливу та маніпулювання, що не відповідає засадам демократичного суспільства.

Відповідно до Рейтингу свободи преси, який формується міжнародною неурядовою правозахисною організацією Freedom House (FH), у 2009-2013 та 2015-2017 pр. українські медіа переважно мали статус «частково вільних», а у 2014 р. були віднесені до категорії «невільних» [17]. Саме 2014 р. було визнано FH «найгіршим періодом в українській історії з часу здобуття незалежності в 1991 році» [5] - протягом року в країні було зафіксовано 7 убивств журналістів [3]. Для порівняння, в Іраку того ж року відбулося 8 убивств журналістів.

За рейтингом «Репортерів без кордонів» у 20092010 рр. позиція України погіршилася з 89 до 131 місця (зі 180 можливих). Причиною було проведення В. Януковичем з моменту обрання його президентом у лютому 2010 р. політики обмеження свободи преси (розбіжності з оцінками $\mathrm{FH}$ пояснюються різницею в методології). Наступні два роки характеризувалися посиленням позиції України до 116 місця. У буремні 2013-2015 рр. збільшилася кількість порушень свободи слова в Україні, що відобразилося зниженням до 129 місця в рейтингу. Підвищення позицій у 20162017 рр. обумовлене зменшенням кількості нападів та інших проявів фізичної агресії щодо журналістів, однак істотними проблемами лишаються тиск на редакторів з боку власників, корупція та «кумівство» [7].

Для моніторингу та захисту свободи слова групою українських та міжнародних журналістів у 1995р. було створено Інститут масової інформації (IMI) - неприбуткову, недержавну громадську організацію. 3 2002 р. в рамках дослідження «Барометр свободи слова» IMI щомісячно друкує звіти щодо зафіксованих 


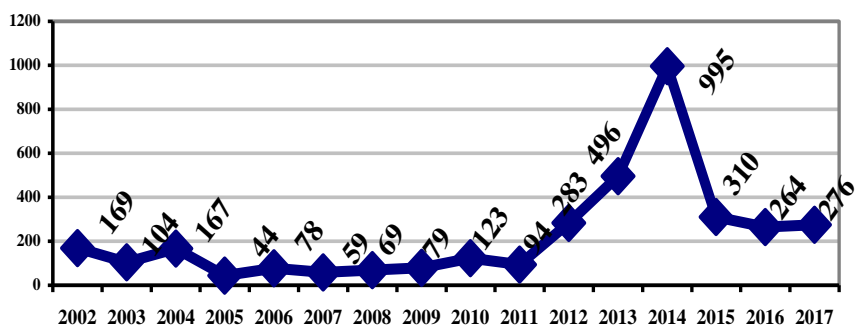

Рисунок 1. Кількість порушень свободи слова в Україні, зафіксовані IMI у 2002-2017 pp. Джерело: складено автором за матеріалами $[1,2,3]$

До Свромайдану зростання кількості порушень свободи слова зазвичай фіксувалося в періоди передвиборчих кампаній (президентські вибори 2004 р. та 2010 р., парламентські вибори 2012 р.).

Події революції гідності, анексія Криму та початок збройного конфлікту на Сході України сприяли істотному збільшенню загроз журналістській діяльності та тиску на 3МI, що стало причиною рекордного зростання кількості порушень свободи слова у 2013-2014 pp.

Хоча у 2015-2017 рр. кількість зафіксованих IMI порушень свободи слова знизилася в порівнянні з попередніми роками, проте все ще спостерігається значне перевищення рівня 2003-2011 рр. Як слушно зазначає В. І. Павликівський, «незважаючи на те, що Україна $€$ учасником практично всіх міжнародних систем контролю за дотриманням свободи слова, слід констатувати недостатню їх ефективність» [10, с. 207].

Формами фактичних проявів порушень свободи слова виступають: перешкоджання законній діяльності журналістів, обмеження доступу до інформації, цензура, погрози, побиття, напади та вбивства представників 3МI, кібер-атаки, пошкодження майна, тиск юридичного, політичного, економічного характеру та інші незаконні дії (напади на офіси редакцій, обшуки, арешти та затримання, недопуск іноземних журналістів тощо).

Досліджуючи особливості проявів порушень свободи слова в Україні за останні п'ять років (див. табл. 1), слід зауважити значне зростання кількості фактів побиття та нападів на представників преси у 20132014 р., що пов'язане з подіями Євромайдану та початком збройного конфлікту на Сході України. Також в цей період 3МІ зіткнулись 3 новим викликом - безпрецедентною кількістю ДДоС-атак та кібер-злочинів, які до 2013 р. взагалі не рахувалися як окрема категорія [1].

Істотне збільшення проявів цензури у 2014 р. пов'язане із активізацією протидії російській пропаганді. Наступний 2015 р. загалом характеризувався зменшенням кількості зафіксованих порушень свободи слова, однак радикалізація українського суспільства призвела до збільшення фізичної агресії проти журналістів, критично налаштованих щодо української влади, АТО, ВСУ та добровольчого руху (в ролі агресорів виступали «представники українських добровольчих батальйонів, громадські активісти, особи з особливим уявленням щодо справедливості»[11, с. 56]) .
У 2016-2017 рр. зменшується рівень проявів фізичної агресії щодо представників медіа, натомість посилюються політичний та юридичний тиск на ЗМI та журналістів, більш частими стають факти обмеження доступу до публічної інформації. Основними формами проявів порушення свободи слова лишаються перешкоджання журналістській діяльності.

Таблиця 1 - Порушення свободи слова в Україні у 20132017 pp.

\begin{tabular}{|l|c|c|c|c|c|}
\hline \multicolumn{1}{|c|}{ Види порушень } & 2013 & 2014 & 2015 & 2016 & 2017 \\
\hline Перешкоджання & 130 & 150 & 100 & 108 & 89 \\
\hline Доступ до інформації & 13 & 14 & 33 & 30 & 41 \\
\hline Цензура & 63 & 146 & 12 & 7 & 0 \\
\hline Погрози & 35 & 98 & 36 & 43 & 37 \\
\hline $\begin{array}{l}\text { Побиття та напади на } \\
\text { представників ЗМІ }\end{array}$ & 101 & 286 & 58 & 30 & 29 \\
\hline Вбивства журналістів & 0 & 7 & 2 & 1 & 0 \\
\hline Кібер-атаки & 49 & 69 & 17 & 11 & 15 \\
\hline Пошкодження майна & 0 & 63 & 0 & 4 & 13 \\
\hline Юридичний тиск & 30 & 12 & 3 & 4 & 12 \\
\hline Політичний тиск & 33 & 39 & 5 & 3 & 10 \\
\hline Економічний тиск & 13 & 10 & 9 & 4 & 0 \\
\hline Інші прояви & 29 & 101 & 35 & 19 & 30 \\
\hline Разом & 496 & 995 & 310 & 264 & 276 \\
\hline
\end{tabular}

Джерело: складено автором за матеріалами $[1,2,3]$

Стосовно суб'єктів агресії та порушників слободи слова в Україні, то протягом 2013-2014 рр. ними переважно були працівники правоохоронних органів та представники місцевих органів влади. У 2015-2017 рр. ситуація змінилася - переважати стали приватні особи (151 випадок або майже 55\%).

В контексті реалізації заходів інформаційної безпеки (відключення російських телеканалів та блокування доступу до ряду інтернет-ресурсів, заборони російським журналістам працювати на території України тощо) і створення у 2015 р. Міністерства у справах інформаційної політики певні представники ОБСЄ висловлювали занепокоєння щодо обмежень свободи слова в Україні [14]. Аналізуючи такі коментарі, доцільно звернутися до міжнародного законодавства та підкреслити дуальний характер ст. 10 Конвенції [8], в якій перераховується низка конкретних випадків, коли втручання держави в журналістську діяльність і обмеження свободи слова є цілком виправданими (за умови передбачення національним законодавством та необхідністю в демократичному суспільстві) [13, с. 137]. Національне законодавство (в першу чергу - ч.3 ст. 34 Конституції України [9]), як і ст. 10 Конвенції [8], фіксує можливість законодавчого 
обмеження права на свободу слова в інтересах національної безпеки, територіальної цілісності або громадського порядку. Таким чином, із врахуванням інформаційної війни та проявів антиукраїнської пропаганди в роботі окремих медіа, реалізацію обмежувальних заходів в рамках зміцнення інформаційної безпеки України щодо російських ЗМІ та інтернетресурсів можна вважати доцільною.

Аналогічні висновки представлені і в результатах дослідження УГСПЛ [16], відповідно до яких Міністерство інформаційної політики не є інструментом тиску на журналістів, а його діяльність у 2015-2017 pp. не мала істотних негативних наслідків для прав людини. Водночас, експертами УГСПЛ наголошується необхідність «подальшого активного моніторингу роботи Міністерства на предмет дотримання прав людини, оскільки архітектура інформаційної безпеки лише вибудовується і є ризик виконання Міністерством функцій, що будуть іти всупереч свободі слова» $[16$, c. 79].

Безумовно, питання національної безпеки в умовах інформаційної війни обумовлюють введення низки обмежень свободи слова, однак реалізація такої державної політики в Україні повинна здійснюватися правовими методами 3 метою захисту основ конституційного ладу, демократії, прав та законних інтересів громадян, із врахуванням міжнародних стандартів в сфері свободи слова, права на істину, етичних принципів роботи мас-медіа, в тому числі - в сфері протидії мові ворожнечі.

Висновки. Таким чином, незважаючи на поступальний рух до європейської спільноти та розвиток демократичних цінностей, в Україні фіксуються численні порушення свободи слова та прав журналістів, основними проявами яких $є$ перешкоджання журналістській діяльності, погрози, побиття та напади на журналістів, обмеження доступу до інформації. Тенденцією 2016-2017 рр. виступає зміна вектору проявів порушень свободи слова в Україні - на фоні зниження рівня фізичної агресії зростають обмеження доступу до публічної інформації, посилюється політичний та юридичний тиск на ЗМІ та журналістів.

В умовах наявної інформаційної війни та збройного конфлікту особливо слід наголосити і на необхідності формування професійних стандартів роботи медіа, дотримання працівниками ЗМІ журналістської етики, об'єктивності та неупередженості при висвітлення подій. Важливим також виступає детальне розслідування та запобігання політичному тиску на журналістів і 3MI, що є неприпустимим в демократичному суспільстві.

\section{ЛІТЕРАТУРА}

1. Барометр свободи слова. 2013 став найгіршим для свободи слова в Україні за останні 11 років. Результати досліджень Інституту масової інформації. 16.01.2014. http://imi.org.ua/news/2013-stav-naygirshim-dlya-svobodislova-v-ukrajini-za-ostanni-11-rokiv/

2. Барометр свободи слова. Свобода слова в Україні у 2012 році. Короткий звіт до Всесвітнього дня свободи преси. 03.05.2013. http://imi.org.ua/articles/svoboda-slova-vukrajini-u-2012-rotsi-korotkiy-zvit-do-vsesvitnogo-dnyasvobodi-presi/

3. Барометр свободи слова. У 2017 році в Україні зафіксовано 274 порушення свободи слова - IMI. 29.12.2017. http://imi.org.ua/news/u-2017-rotsi-v-ukrajini-zafiksovano274-porushennya-svobody-slova-imi/

4. Бондар Ю. В. Свобода слова: книга і політика / Ю. В. Бондар. К.: [б. в.], 2011. 111 с.

5. Дисюк О. Право на голос: Історія свободи слова в Україні. 10.12.2015. https://ua.112.ua/statji/pravo-na-holos-istoriiasvobody-slova-v-ukraini-277826.html

6. Заславська О. О. Засоби масової інформації як інструмент моделювання політичної свідомості у виборчій кампанії (на матеріалах президентських і парламентських виборів 2004-2006 рр.): дис. . канд. політ. наук: 23.00.03 / Заславська О. О.; Київський національний ун-т ім. Тараса Шевченка. Інститут журналістики. К., 2008. 243 с.

7. Інфографіка: Рейтинг свободи слова. Україна між Бразилією і Гвінеєю. Матеріали інформаційного агентства ЛІГАБізнесІнформ.

27.04.2017 http://www.liga.net/infografica/330677_reyting-svobodyslova-ukraina-mezhdu-braziliey-i-gvineey.htm

8. Конвенція про захист прав людини і основоположних свобод (ратифіковано Законом № 475/97-ВР від 17.07.97). http://zakon0.rada.gov.ua/laws/show/995_004

9. Конституція України. Закон від 28.06.1996 № 254к/96-ВР (в редакції від http://zakon2.rada.gov.ua/laws/show/254к/96-вр

10. Павликівський В. І. Світові стандарти свободи слова та ïx значення для вдосконалення кримінального законодавства України // Вісник Асоціації кримінального права України. 2014. №2 (3). С. 197-207.

11. Приглушені голоси: право на свободу слова в умовах збройного конфлікту на сході України / О. А. Біда, А. Б. Блага, О. А. Мартиненко, М. Г. Статкевич; за заг. ред. А. П. Бущенка / Українська Гельсінська спілка з прав людини. К., КИТ, 2015. 60 с.

12. Приступенко Т. О. Теорія журналістики: етичні та правові засади діяльності засобів масової інформації : навч. посібник / Т. О. Приступенко. К. : Знання, 2011. 351 с.

13. Приступенко Т.О. ЗМІ та влада: право на інформацію / Т.О. Приступенко // Культура народов Причерноморья. 2007. № 101. C. 134-142/

14. Пропаганда и свобода массовой информации. Памятная записка Бюро Представителя ОБСЕ по вопросам свободы СМИ. Вена, 2015 http://www.osce.org/ru/fom/219726?download=true

15. Романенко Т. В. Свобода слова в недійному просторі сучасної України // Молодий вчений. 2016. №12 (40). С. 275-278.

16. Свобода слова в умовах інформаційної війни та збройного конфлікту / А.Б. Блага, О.А. Мартиненко, Б.С. Мойса, Р.В. Шутов; за заг. ред. О.А. Мартиненка/ Українська Гельсінська спілка 3 прав людини. К., 2017. 85 с.

17. Freedom House. Freedom of the Press. https://freedomhouse.org/report/freedom-press/

\section{REFERENCES}

1. Barometer of freedom of speech. 2013 has become worst for freedom of speech in Ukraine over the past 11 years. Research results of the Institute of Mass Information.

16.01.2014. http://imi.org.ua/news/2013-stav-naygirshimdlya-svobodi-slova-v-ukrajini-za-ostanni-11-rokiv/

2. Barometer of freedom of speech. Freedom of speech in Ukraine in 2012. Brief report to the World Press Freedom 
Day. 03.05.2013. http://imi.org.ua/articles/svoboda-slova-vukrajini-u-2012-rotsi-korotkiy-zvit-do-vsesvitnogo-dnyasvobodi-presi/

3. Barometer of freedom of speech. In 2017, Ukraine recorded 274 violations of freedom of speech - IMM. 29.12.2017. http://imi.org.ua/news/u-2017-rotsi-v-ukrajini-zafiksovano274-porushennya-svobody-slova-imi/

4. Bondar Yu. V. Freedom of speech: book and politics / Yu. V. Bondar. K.: [b. v.], 2011. $111 \mathrm{c}$.

5. Dysyuk O. The Right to the Voice: The History of Freedom of Speech in Ukraine. 10.12.2015. https://ua.112.ua/statji/pravona-holos-istoriia-svobody-slova-v-ukraini-277826.html

6. Zaslavska O. O. Mass media as an instrument for modeling political consciousness in an election campaign (on materials of presidential and parliamentary elections 2004-2006): diss. Cand. flight. Sciences: 23.00.03 / Zaslavskaya O. O .; Kyiv National University. Taras Shevchenko. Institute of Journalism. K., 2008. 243 c.

7. Infographics: Freedom of expression rating. Ukraine between Brazil and Guinea. Materials of the information agency LIGABusinessInform. 27.04.2017. http://www.liga.net/infografica/330677_reyting-svobodyslova-ukraina-mezhdu-braziliey-i-gvineey.htm

8. The Convention for the Protection of Human Rights and Fundamental Freedoms (ratified by the Law No. 475/97-BP of 17.07.97). http://zakon0.rada.gov.ua/laws/show/995_004

9. The Constitution of Ukraine. Law dated June 28, 1996 No. $254 \mathrm{~K} /$ 96-BP (as amended from 09.30.2016). http://zakon2.rada.gov.ua/laws/show/254к/96-вp
10. Pavlykivsky V. I. World standards of freedom of speech and their significance for improvement of criminal legislation of Ukraine // Bulletin of the Association of Criminal Law of Ukraine. 2014. №2 (3). P. 197-207.

11. Mute voices: the right to freedom of speech in conditions of armed conflict in the east of Ukraine / O. A. Bida, A. B. Blaga, O. A. Martynenko, M. G. Statkevich; per community Ed. A.P. Buschenko / Ukrainian Helsinki Human Rights Union. K., KIT, 2015. 60 p.

12. Pristupenko T.O. Theory of Journalism: Ethical and Legal Principles of Mass Media Activity: Teaching. manual / T. O. Pristupenko. K. Znannya, 2011.351 p.

13. Pristupenko T.O. Media and power: the right to information / T.O. Pristupenko // Culture of the peoples of the Black Sea region. 2007. № 101. P. 134-142

14. Propaganda and freedom of mass information. Memorandum of the Office of the OSCE Representative on Freedom of the Media. Vein, 2015 http://www.osce.org/ru/fom/219726?download=true

15. Romanenko T.V. Freedom of speech in media space of modern Ukraine // «Young Scientist» • № 12.1 (40) • december, 2016. P. 275-278.

16. Freedom of speech in conditions of information warfare and armed conflict / A.B. Blaga, O.A. Martynenko, B.S. Moses, R.V. Shooters; general editions O.A. Martynenko / Ukrainian Helsinki Human Rights Union. K., 2017. 85 p.

17. Freedom House. Freedom of the Press. https://freedomhouse.org/report/freedom-press/

\section{Freedom of speech in Ukraine}

\section{T. O. Prystupenko}

Abstract. The urgency of observance of freedom of speech for modern Ukrainian society is grounded. The changes in the state of freedom of speech in Ukraine are estimated by international ratings and the Ukrainian Institute of Mass Information. The changes in manifestations of violations of freedom of speech in 2013-2017 are considered. The expediency of implementing information security measures to limit the activities of Russian media and their compliance with international and national legislation on freedom of speech was proved.

Keywords: freedom of speech, mass media, media, journalistic activity, violations of freedom of speech.

\section{Свобода слова в Украине \\ Т. О. Приступенко}

Аннотация. Обоснована актуальность соблюдения свободы слова для современного украинского общества. Исследованы изменения состояния свободы слова в Украине по оценкам международных рейтингов и украинского Института массовой информации. Рассмотрены изменения проявлений нарушений свободы слова в 2013-2017 гг. Доказана целесообразность реализации мероприятий информационной безопасности по ограничению деятельности российских СМИ и их соответствие международному и национальному законодательству о свободе слова.

Ключевые слова: свобода слова, средства массовой информации, медиа, журналистская деятельность, нарушения свободы слова. 